\title{
Effects of exercise training on cardiovascular adrenergic system
}

\section{Dario Leosco *, Valentina Parisi, Grazia D. Femminella, Roberto Formisano, Laura Petraglia, Elena Allocca and Domenico Bonaduce}

Department of Translational Medical Sciences, University of Naples "Federico II," Naples, Italy

\section{Edited by:}

Arto J. Hautala, Verve Research,

Finland

Reviewed by:

Walter J. Koch, Temple University

School of Medicine, USA

Giovanni Esposito, University of

Naples "Federico II," Italy

*Correspondence:

Dario Leosco, Department of

Translational Medical Sciences,

University of Naples "Federico II,"

Via S. Pansini, 5 - 80131 Naples, Italy

e-mail:dleosco@unina.it
In heart failure (HF), exercise has been shown to modulate cardiac sympathetic hyperactivation which is one of the earliest features of neurohormonal derangement in this syndrome and correlates with adverse outcome. An important molecular alteration related to chronic sympathetic overstimulation in $\mathrm{HF}$ is represented by cardiac $\beta$-adrenergic receptor $(\beta-A R)$ dysfunction. It has been demonstrated that exercise reverses $\beta$-AR dysfunction by restoring cardiac receptor membrane density and G-protein-dependent adenylyl cyclase activation. In particular, several evidence indicate that exercise reduces levels of cardiac G-protein coupled receptor kinase-2 (GRK2) which is known to be involved in both $\beta 1-A R$ and $\beta 2-A R$ dysregulation in HF. Similar alterations of $\beta$-AR system have been described also in the senescent heart. It has also been demonstrated that exercise training

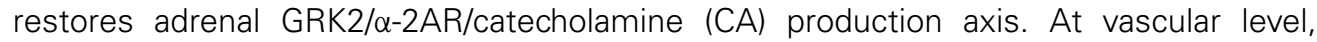
exercise shows a therapeutic effect on age-related impairment of vascular reactivity to adrenergic stimulation and restores $\beta$-AR-dependent vasodilatation by increasing vascular $\beta$-AR responsiveness and reducing endothelial GRK2 activity. Sympathetic nervous system overdrive is thought to account for $>50 \%$ of all cases of hypertension and a lack of balance between parasympathetic and sympathetic modulation has been observed in hypertensive subjects. Non-pharmacological, lifestyle interventions have been associated with reductions in SNS overactivity and blood pressure in hypertension. Several evidence have highlighted the blood pressure lowering effects of aerobic endurance exercise in patients with hypertension and the significant reduction in sympathetic neural activity has been reported as one of the main mechanisms explaining the favorable effects of exercise on blood pressure control.

Keywords: exercise, heart failure, adrenergic system, aging process, systemic hypertension

\section{INTRODUCTION}

It has been generally accepted that regular physical activity is associated with beneficial effects on the cardiovascular system (Belardinelli et al., 1999; Hambrecht et al., 2000; Piepoli et al., 2004; Rinaldi et al., 2006; Flynn et al., 2009; Giallauria et al., 2013). In fact, the idea that exercise maintains cardiovascular health is evident by the direct links between a sedentary lifestyle and the risk of cardiovascular and other disease states. Cardiovascular diseases, such as heart failure (HF) and hypertension, and impairment of cardiovascular reserve observed with aging, are often associated with SNS overactivity (Francis and Cohn, 1986; Brodde et al., 1995a; Kaye et al., 1995; Davies et al., 1996; Julius and Nesbitt, 1996; Ferrara et al., 1997a,b; Xiao et al., 1998; Seals and Esler, 2000; Kilts et al., 2002; Schlaich et al., 2004). Conversely, exercise has been shown to decrease elevated SNS activity in HF, hypertension and in the aging heart and vasculature. Although somewhat controversial in humans, evidence from animal studies also indicates that exercise training reduces baroreflex-mediated and other forms of sympathoexcitation in normal individuals. Collectively, these data are consistent with the hypothesis that physical activity may decrease the incidence of cardiovascular disease and improve cardiac outcome via alterations in SNS activity. Despite the important clinical implications of this possibility, the mechanisms by which exercise alters control of SNS activity remain to be fully elucidated. The aim of this review is to focus on the pathophysiological mechanisms by which exercise can modulate SNS overactivity and exert its favorable effect on the onset and progression of cardiovascular diseases.

\section{EFFECTS OF EXERCISE ON SNS HYPERACTIVITY IN HEART FAILURE}

Sympathetic activation has been shown to be one of the earliest features of neurohormonal rearrangement in $\mathrm{HF}$ where the prolonged exposure to pathological levels of catecholamines (CAs) are associated with adverse outcome (Kaye et al., 1995; Marciano et al., 2012; Paolillo et al., 2013; Rengo et al., 2013a; Savarese et al., $2013)$. In this process, cardiac $\beta$-adrenergic receptor ( $\beta$-AR) dysfunction seems to be crucial (Bristow et al., 1986; Ungerer et al., 1993; Brodde et al., 1995b; Xiao et al., 1999; Rockman et al., 2002; Giallauria et al., 2010; Rengo et al., 2012a; Femminella et al., 2013), in particular downregulation/desensitization of $\beta 1-A R$, 
and prevalent desensitization/uncoupling of $\beta 2$-AR. In particular, the receptors dysfunction seem to be related to increased levels of cardiac G-protein coupled receptor kinase-2 (GRK2). GRK2 is a kinase that phosphorylates intracellular domains of activated receptors, leading to the recruitment of arrestins to the receptors and the attenuation of intracellular $G$ protein-dependent signaling. Therefore, GRK2 phosphorylates receptors and uncouples them from the adenylyl cyclase effector system (Rengo et al., 2012a). The relevance of cardiac GRK2 up-regulation in failing myocardium is supported by the observation of the therapeutic effect exerted by its inhibition (Salazar et al., 2013). Interestingly, GRK2 inhibition reverses left ventricular (LV) remodeling and improves myocardial contractility in the failing heart (Raake et al., 2008; Rengo et al., 2009, 2011, 2012a,b,c; Ciccarelli et al., 2011; Lymperopoulos et al., 2012).

Since it has been demonstrated that myocardial GRK2 levels and activity mirror those measured in peripheral lymphocytes in HF patients (Iaccarino et al., 2005), it could be possible to monitor the efficacy of different therapies using circulating white blood cells (Rengo et al., 2013b).

Exercise training in patients with stable HF, can relieve symptoms, improve exercise capacity and quality of life, and reduce disability, hospitalization, and mortality (Piepoli et al., 2004; van Tol et al., 2006). Physical inactivity can thus be considered a major cardiovascular risk factor and current treatment guidelines recommend exercise training in patients with HF in NYHA functional classes II and III (Hunt et al., 2005; Rinaldi et al., 2006). Exercise training is associated with numerous pulmonary, cardiovascular, and skeletal muscle metabolic adaptations that are beneficial.

The crucial role of $\beta$-AR dysregulation in the pathophysiology of HF is well established. GRK2, which plays a key role in the regulation of $\beta$-AR, is significantly elevated in human and experimental HF (Ungerer et al., 1993; Gros et al., 2000; Rockman et al., 2002; Petrofski and Koch, 2003; Iaccarino et al., 2005). Moreover, molecular manipulations of $\beta$-AR utilizing GRK2 inhibitors, such as the peptide known as the $\beta A R K c t$, restore $\beta$-AR signaling in the heart and increase cardiac function (Koch et al., 1995; Rockman et al., 1998; Harding et al., 2001; Shah et al., 2001). A significant reduction of cardiac GRK2 expression has been also recognized as a potential mechanism by which selective and non-selective $\beta$-AR blockade may positively affect $\beta$-AR signaling (Iaccarino et al., 1998; Leosco et al., 2007; Cannavo et al., 2013a; Rengo et al., 2013c). Previous works have shown that exercise is able to decrease GRK2 myocardial levels and improve $\beta$-AR signaling and responsiveness in spontaneously hypertensive rats (SHR) (MacDonnell et al., 2005) as well as in the aged heart (Leosco et al., 2007). More recently, it has been demonstrated that training evokes similar effects on $\beta$-AR system also in the post-ischemic hypertrophied failing myocardium leading to an enhanced cardiac inotropic state at the adrenergic stimulation (Leosco et al., 2008). Similar observation also have been reported in post-MI exercised mice (de Waard et al., 2007) that show increased cardiac $\beta$-AR protein and cAMP levels in the exercise animal group but these findings are not associated with significant changes of GRK2 protein levels. In this vein, it has been demonstrated that the mechanisms of $\beta$-AR desensitization may be GRK2- dependent
(MacDonnell et al., 2005) or GRK2-independent (Xiao et al., 1994). Importantly, the observation of improved $\beta$-AR responses also in intact cardiomyocytes of post-infarcted failing hearts indicate that training may restore receptor signaling alterations in remote non-infarcted myocardium contributing to LV dysfunction (Leosco et al., 2008; Cannavo et al., 2013b). It still remains an unresolved issue why exercise does not seem to affect basal LV contractility in failing hearts (Musch et al., 1986; Gaudron et al., 1994) despite the improved $\beta$-AR function. Consistent with this is the observation that basal cAMP production, which remains still depressed in exercised HF animals, is unchanged, since adenylyl cyclase activity and cardiac contraction via protein kinase A mediated downstream effects are closely interlinked (Georget et al., 2002). This finding strongly supports the importance of downstream cellular events in the improvement of $\beta$-AR signaling and responsiveness in the failing heart.

\section{EFFECTS OF EXERCISE ON ADRENAL $\alpha 2-A R s$ DYSREGULATION IN HEART FAILURE}

As mentioned above, exercise training appears to reduce autonomic derangement and neurohumoral excitation at rest in HF. The effects of exercise training on adrenergic hyperactivation in HF patients have not been completely clarified. Recently, an important molecular mechanism has been identified that contributes to the sympathetic overdrive of the failing heart. This mechanism involves the upregulation of GRK2 in adrenal medulla of HF animals, which leads to downregulation and $G$ protein uncoupling of the $\alpha 2$-ARs present in the chromaffin cell membranes of the adrenal gland that normally exert negative feedback control on CA turnover (Lymperopoulos et al., 2007a; Rengo et al., 2012a,b,c,d,e). Thus, dysfunction of these receptors results in chronically elevated CA secretion and circulating levels in HF (Lymperopoulos et al., 2007a). More recently, a novel molecular neurohormonal mechanism has been reported to explain the effects of exercise training on counterbalancing sympathetic overactivation and the enhanced circulating CA levels of chronic HF that significantly increase the morbidity and mortality of this devastating disease. This mechanism involves lowering and restoration of adrenal GRK2 levels/activity, which results in marked reduction of adrenal CA production and secretion via decreased adrenal $\alpha 2-\mathrm{AR}$ desensitization/downregulation and normalization of circulating CA levels (Rengo et al., 2010). This finding is of particular importance because several studies have reported that exercise training counteracts the catecholaminergic activation of chronic HF in humans and in several animal models of the disease (Gademan et al., 2007; Lymperopoulos et al., 2007a,b; Rengo et al., 2009); however, essentially no evidence has been provided to mechanisms mediating this beneficial effect of this modality in HF. Circulating CAs originate from the adrenal medulla in the form of Epinephrine and Norepinephrine, which are secreted at a ratio of $80-20 \%$, respectively, under normal conditions (Lymperopoulos et al., 2007b). Spilled-over Norepinephrine produced at sympathetic nerve endings also contributes to the total circulating amount of CA. Adrenal CA production is under tight regulation by sympathoinhibitory $\alpha 2-\mathrm{ARs}$, which are expressed in the adrenal medulla and inhibit CA release (Lymperopoulos et al., 2007b). a2-AR function in turn is regulated by GRK2, 
which phosphorylates and desensitizes the $\alpha 2-\mathrm{AR}$, thus suppressing its function (Petrofski and Koch, 2003). By reducing GRK2 activity on adrenal $\alpha 2$-ARs, exercise training appears to restore adrenal $\alpha 2$-AR number and CA feedback inhibition, and this represents a mechanism whereby it reduces circulating CA levels in chronic HF.

\section{EFFECTS OF EXERCISE ON AGE-RELATED CARDIAC AND VASCULAR $\beta$-AR DYSREGULATION}

Noteworthy, alterations of $\beta$-AR system, similar to those observed in HF, have been described also in the senescent heart (Davies et al., 1996; Ferrara et al., 1997a,b; Rengo et al., 2012a,b,c,d,e). With aging, sympathetic activity is increased and cardiac neuronal uptake of CA is decreased. Although alterations in Gscoupled receptors in the failing and aging human heart are quite comparable, GRK2 activity seems to be not affected by age (Xiao et al., 1998). In this vein, animal studies demonstrated that the positive inotropic effects after both $\beta 1$ - and $\beta 2$-AR stimulation are markedly decreased in myocardium of aged rats as a consequence of a lower density of receptors and a diminished adenylyl cyclase activity. There have been conflicting reports about the effect of age on cardiac inhibitory $\mathrm{G}$ protein $(\mathrm{Gi})$ levels in both humans and rodents. In one study of human heart, Gi levels were measured in atrial appendages received from surgical patients, and it was found that Gi expression increased with age (Brodde et al., 1995a,b). Accordingly, age-dependent Gi upregulation has been documented in animal models. This observation is particularly relevant since $\beta 2-\mathrm{AR}$ signaling couples to $\mathrm{Gi}$ proteins as well as to stimulatory G proteins (Gs) (Kilts et al., 2002). In contrast, some authors reported that neither GRKs nor Gi proteins appear to contribute to the age-related reduction in cardiac $\beta$-AR responsiveness (Xiao et al., 1998). This evidence can be the consequence of a delayed progression of sympathetic activity dysfunction in the elderly, while in HF it develops much more rapidly (Brodde et al., 1995a,b; Kilts et al., 2002). Thus, time course and intensity of increase in sympathetic activity can explain the different behavior of GRK activity in the aging and failing human heart.

Exercise has been shown to modulate GRK2 levels/activity by reducing levels of this kinase in the heart and, consequently, inducing $\beta$-AR "resensitization." It has been previously demonstrated in rats that both exercise and $\beta$-blockers reverse $\beta$-AR dysfunction by restoring cardiac receptor membrane density and G-protein-dependent adenylyl cyclase activation (Leosco et al., 2007). Of note, although cardiac GRK2 levels were not upregulated in old sedentary rats compared to young sedentary rats, exercise resulted in a significant reduction of GRK2 activity even at lower levels than those observed in young controls. This latter phenomena represents a further demonstration of the beneficial effects of physical activity on $\beta$-AR signaling. Furthermore, Böhm et al. have demonstrated that exercise can partially reverse depression in cAMP production due to age-dependent Gi alpha increased expression (Böhm et al., 1993).

At vascular level, studies conducted in the aorta and carotid arteries of old rats have shown a reduced $\beta$-AR-dependent vasorelaxation (Chapman et al., 1999; Schutzer et al., 2001; Leosco et al., 2003). Importantly, $\beta$-AR dysfunction observed in the aorta and carotids of old rats is mainly due to GRK2 upregulation that seems to have a crucial pathogenic role in age-related vascular $\beta$-AR dysfunction. Importantly, exercise shows a therapeutic effect on age-related impairment of vascular reactivity to adrenergic stimulation and restores $\beta$-AR-dependent vasodilatation by increasing vascular $\beta$-AR responsiveness and by reducing endothelial GRK2 activity (Leosco et al., 2003).

In old healthy subjects, it has been demonstrated that physical training ameliorates age-related deterioration of cardiac function in terms of enhanced LV inotropic response to CA (Ehsani et al., 1991; Stratton et al., 1994; Spina et al., 1998). Contrasting data have been reported by other authors who described unchanged LV systolic performance (Stratton et al., 1992) in response to adrenergic stimulation after training in the elderly. However, it is important to underline that exercise training also enhances vagal tone (Levy et al., 1966), which could mask the favorable effect of exercise on cardiac $\beta$-adrenergic responsiveness.

\section{EFFECTS OF EXERCISE ON NEURAL REGULATION OF BLOOD PRESSURE}

The most common form of hypertension is neurogenic hypertension that is associated with sympathetic overdrive, loss of parasympathetically mediated cardiac variability, and excessive angiotensin II activity (Esler, 2010). Evidence from studies in both patients and animal models of hypertension strongly implicate the chronic sympathetic neural activation in the etiology and progression of hypertension (Anderson et al., 1989; Smith et al., 2002, 2004; Simms et al., 2009; Esler, 2010). Studies in adult SHR have also identified a reduced cardiac parasympathetic nerve activity (Friberg et al., 1988), elevated SNS activity and increased noradrenaline release (Judy and Farrell, 1979; Lundin et al., 1984). Notably, neonatal sympathectomy prevents the SHR from developing hypertension (Cabassi et al., 1998), and SNS is elevated in young SHR prior to the development of hypertension (Korner et al., 1993). In humans, it has been estimated that a neurogenic component is observed in $40-65 \%$ of hypertensive patients and different studies report an increase of $100-200 \%$ of SNS activity in the brain, heart, kidneys, and skeletal muscle vasculature (Esler et al., 1988; Grassi et al., 1998a; Huggett et al., 2004; Lambert et al., 2007). The magnitude of the elevation in SNS is related to the magnitude of hypertension (Grassi, 1998; Grassi et al., 1998b). Indeed, it has been described that the increase in blood pressure from control subjects to mildly hypertensive, and to more severely hypertensive patients is associated with a parallel increase in muscle SNS activity (Grassi et al., 1998b).

Clinical interventions showing impressive blood pressure lowering effects by targeting reductions in SNS activation (Krum et al., 2009, 2011; Wustmann et al., 2009; Esler et al., 2010) have contributed to a better understanding of the central sympathetic regulatory pathways altered in hypertension, and have stressed the importance in the control of the sympathetic nervous system in hypertension and its utility as a clinical target. Exercise has been shown to reduce SNS hyperactivity and blood pressure in hypertension. There are important mechanistic data from animal studies to show that exercise training limits sympathoexcitation and favors sympathoinhibition in the brainstem cardiovascular centers (Mueller, 2007). Previous studies have highlighted the 
blood pressure lowering effects of aerobic endurance exercise training in patients with hypertension (Esler et al., 2010). Indeed, regular, moderate intensity training is associated with a $10 \mathrm{mmHg}$ average fall in systolic and diastolic blood pressure in hypertensive patients (American College of Sports Medicine, 1993). In this regard, it has been reported that a 4-month programme of aerobic exercise training reduces of $\sim 37 \%$ muscle SNS activity and blood pressure in never-treated hypertensive patients (Laterza et al., 2007).

Exercise training could elicit adaptations in the adrenergic system, since SNS is activated during each bout of exercise and repeated activation of SNS may result in an attenuation of sympathetic activity (Grassi et al., 2000). Animal studies suggested that nitric oxide decreased overall sympathetic excitability within the brainstem and possibly through actions in higher brain regions (Goodson et al., 1994; Patel et al., 1996). It is unclear whether the increased release of nitric oxide during exercise training has a central sympathoinhibitory effect in humans. Previous studies demonstrated that hyperinsulinemia and insulin resistance were associated with hypertension and sympathetic activation (Julius et al., 1991; Baron et al., 1993). Trainingdependent improvement of insulin sensitivity in normotensive and hypertensive individuals (Kohno et al., 2000; Henriksen, 2002) could contribute to attenuate insulin mediated sympathetic activation.

\section{CONCLUSIONS}

SNS overactivity is common in many cardiovascular disease states and is related to a higher incidence of morbidity and mortality. It is widely accepted that exercise training is associated with reductions in SNS activity, whether at rest or during conditions that produced sympathoexcitation, and this effect may represent an important mechanism by which exercise may contribute to long term cardiovascular health. Future studies are needed to further identify the molecular mechanisms that are involved in physical activity dependent changes in the control of SNS activity.

\section{REFERENCES}

American College of Sports Medicine. (1993). Position stand. Physical activity, physical fitness, and hypertension. Med. Sci. Sports Exerc. 25, i-x. doi: 10.1249/00005768-199310000-00024

Anderson, E. A., Sinkey, C. A., Lawton, W. J., and Mark, A. L. (1989). Elevated sympathetic nerve activity in borderline hypertensive humans. Evidence from direct intraneural recordings. Hypertension 14, 177-183. doi: 10.1161/01.HYP.14.2.177

Baron, A. D., Brechtel-Hook, G., Johnson, A., and Hardin, D. (1993). Skeletal muscle blood flow. A possible link between insulin resistance and blood pressure. Hypertension 21, 129-135. doi: 10.1161/01.HYP.21.2.129

Belardinelli, R., Georgiou, D., Cianci, G., and Purcaro, A. (1999). Randomized, controlled trial of long-term moderate exercise training in chronic heart failure: effects on functional capacity, quality of life, and clinical outcome. Circulation 99, 1173-1182. doi: 10.1161/01.CIR.99.9.1173

Böhm, M., Dorner, H., Htun, P., Lensche, H., Platt, D., and Erdmann, E. (1993). Effects of exercise on myocardial adenylate cyclase and $\mathrm{Gi}$ alpha expression in senescence. Am. J. Physiol. 264, H805-H814.

Bristow, M. R., Ginsberg, R., Umans, V., Fowler, M., Minobe, W., Rasmussen, R., et al. (1986). $\beta 1$ - and $\beta 2$-Adrenergic receptor subpopulations in nonfailing and failing human ventricular myocardium: coupling of both receptor subtypes to muscle contraction and selective b1 receptor down-regulation in heart failure. Circ. Res. 59, 297-309. doi: 10.1161/01.RES.59.3.297
Brodde, O. E., Zerkowski, H. R., Schranz, D., Broede-Sitz, A., Michel-Reher, M., Schäfer-Beisenbusch, E., et al. (1995a). Age-dependent changes in the betaadrenoceptor-G-protein(s)-adenylyl cyclase system in human right atrium. J. Cardiovasc. Pharmacol. 26, 20-26. doi: 10.1097/00005344-199507000-00004

Brodde, O. E., Michel, M. C., and Zerkowski, H. R. (1995b). Signal transduction mechanisms controlling cardiac contractility and their alterations in chronic heart failure. Cardiovasc. Res. 30, 570-584. doi: 10.1016/S00086363(95)00152-2

Cabassi, A., Vinci, S., Calzolari, M., Bruschi, G., and Borghetti, A. (1998). Regional sympathetic activity in pre-hypertensive phase of spontaneously hypertensive rats. Life Sci. 62, 1111-1118. doi: 10.1016/S0024-3205(98)00034-4

Cannavo, A., Rengo, G., Liccardo, D., Pagano, G., Zincarelli, C., De Angelis, M. C., et al. (2013a). $\beta 1$-adrenergic receptor and sphingosine-1-phosphate receptor 1 reciprocal down-regulation influences cardiac hypertrophic response and progression toward heart failure: protective role of S1PR1 cardiac gene therapy. Circulation 128, 1612-1622. doi: 10.1161/CIRCULATIONAHA.113. 002659

Cannavo, A., Rengo, G., Liccardo, D., Pironti, G., Scimia, M. C., Scudiero, L., et al. (2013b). Prothymosin alpha protects cardiomyocytes against ischemiainduced apoptosis via preservation of Akt activation. Apoptosis 18, 1252-1261. doi: 10.1007/s10495-013-0876-9

Chapman, J., Schutzer, W. E., Watts, V. J., and Mader, S. L. (1999). Impaired cholera toxin relaxation with age in rat aorta. J. Gerontol. A Biol. Sci. Med. Sci. 54, B154-B159. doi: 10.1093/gerona/54.4.B154

Ciccarelli, M., Chuprun, J. K., Rengo, G., Gao, E., Wei, Z., Peroutka, R. J., et al. (2011). G protein-coupled receptor kinase 2 activity impairs cardiac glucose uptake and promotes insulin resistance after myocardial ischemia. Circulation 123, 1953-1962. doi: 10.1161/CIRCULATIONAHA.110.988642

Davies, C. H., Ferrara, N., and Harding, S. E. (1996). Beta-adrenoceptor function changes with age of subject in myocytes from non-failing human ventricle. Cardiovasc. Res. 31, 152-156. doi: 10.1016/S0008-6363(95)00187-5

de Waard, M. C., van der Velden, J., Bito, V., Ozdemir, S., Biesmans, L., Boontje, N. M., et al. (2007). Early exercise training normalizes myofilament function and attenuates left ventricular pump dysfunction in mice with a large myocardial infarction. Circ. Res. 100, 1079-1088. doi: 10.1161/01.RES.0000262655.16373.37

Ehsani, A. A., Ogawa, T., Miller, T. R., Spina, R. J., and Jilka, S. M. (1991). Exercise training improves left ventricular systolic function in older men. Circulation 83 , 96-103. doi: 10.1161/01.CIR.83.1.96

Esler, M. (2010). The 2009 Carl Ludwig lecture: pathophysiology of the human sympathetic nervous system in cardiovascular diseases: the transition from mechanisms to medical management. J. Appl. Physiol. 108, 227-237. doi: 10.1152/japplphysiol.00832.2009

Esler, M., Jennings, G., Korner, P., Willett, I., Dudley, F., Hasking, G., et al. (1988). Assessment of human sympathetic nervous system activity from measurements of norepinephrine turnover. Hypertension 11, 3-20. doi: 10.1161/01. HYP.11.1.3

Esler, M. D., Krum, H., Sobotka, P. A., Schlaich, M. P., Schmieder, R. E., and Bohm, M. (2010). Renal sympathetic denervation in patients with treatmentresistant hypertension (The Symplicity HTN-2 Trial): a randomized controlled trial. Lancet 376, 1903-1909. doi: 10.1016/S0140-6736(10)62039-9

Femminella, G. D., Rengo, G., Pagano, G., de Lucia, C., Komici, K., Parisi, V., et al. (2013). $\beta$-adrenergic receptors and $G$ protein-coupled receptor kinase-2 in Alzheimer's disease: a new paradigm for prognosis and therapy. J. Alzheimers Dis. 34, 341-347. doi: 10.3233/JAD-121813

Ferrara, N., Böhm, M., Zolk, O., O’Gara, P., and Harding, S. E. (1997a). The role of Gi-proteins and beta-adrenoceptors in the age-related decline of contraction in guinea-pig ventricular myocytes. J. Mol. Cell. Cardiol. 29, 439-448. doi: 10.1006/jmcc.1996.0397

Ferrara, N., Davia, K., Abete, P., Rengo, F., and Harding, S. E. (1997b). Alterations in beta-adrenoceptor mechanisms in the aging heart. Relationship with heart failure. Aging 9, 391-403.

Flynn, K. E., Piña, I. L., Whellan, D. J., Lin, L., Blumenthal, J. A., Ellis, S. J., et al. (2009). Effects of exercise training on health status in patients with chronic heart failure: HF-ACTION randomized controlled trial. JAMA 301, 1451-1459. doi: 10.1001/jama.2009.457

Francis, G. S., and Cohn, J. N. (1986). The autonomic nervous system in congestive heart failure. Annu. Rev. Med. 37, 235-247. doi: 10.1146/annurev.me.37.020186.001315 
Friberg, P., Karlsson, B., and Nordlander, M. (1988). Sympathetic and parasympathetic influence on blood pressure and heart rate variability in Wistar-Kyoto and spontaneously hypertensive rats. J. Hypertens. Suppl. 6, S58-S60.

Gademan, M. G., Swenne, C. A., Verwey, H. F., van der Laarse, A., Maan, A. C., van de Vooren, H., et al. (2007). Effect of exercise training on autonomic derangement and neurohumoral activation in chronic heart failure. J. Card. Fail. 13, 294-303. doi: 10.1016/j.cardfail.2006.12.006

Gaudron, P., Hu, K., Schamberger, R., Budin, M., Walter, B., and Ertl, G. (1994). Effect of endurance training early or late after coronary artery occlusion on left ventricular remodeling, hemodynamics, and survival in rats with chronic transmural myocardial infarction. Circulation 89, 402-412. doi: 10.1161/01.CIR.89.1.402

Georget, M., Mateo, P., Vandecasteele, G., Jurevicius, J., Lipskaia, L., Defer, N., et al. (2002). Augmentation of cardiac contractility with no change in L-type Ca2+ current in transgenic mice with a cardiac-directed expression of the human adenylyl cyclase type 8 (AC8). FASEB J. 16, 1636-1648. doi: 10.1096/fj.020292fje

Giallauria, F., Acampa, W., Ricci, F., Vitelli, A., Torella, G., Lucci, R., et al. (2013). Exercise training early after acute myocardial infarction reduces stress-induced hypoperfusion and improves left ventricular function. Eur. J. Nucl. Med. Mol. Imaging 40, 315-324. doi: 10.1007/s00259-012-2302-x

Giallauria, F., Cirillo, P., Lucci, R., Pacileo, M., D’Agostino, M., Maietta, P., et al. (2010). Autonomic dysfunction is associated with high mobility group box-1 levels in patients after acute myocardial infarction. Atherosclerosis 208, 280-284. doi: 10.1016/j.atherosclerosis.2009.07.025

Goodson, A. R., Leibold, J. M., and Gutterman, D. D. (1994). Inhibition of nitric oxide synthesis augments centrally induced sympathetic coronary vasoconstriction in cats. Am. J. Physiol. 267, H1272-H1278.

Grassi, G. (1998). Role of the sympathetic nervous system in human hypertension. J. Hypertens. 16, 1979-1987. doi: 10.1097/00004872-199816121-00019

Grassi, G., Colombo, M., Seravalle, G., Spaziani, D., and Mancia, G. (1998a). Dissociation between muscle and skin sympathetic nerve activity in essential hypertension, obesity, and congestive heart failure. Hypertension 31, 64-67. doi: 10.1161/01.HYP.31.1.64

Grassi, G., Cattaneo, B. M., Seravalle, G., Lanfranchi, A., and Mancia, G. (1998b). Baroreflex control of sympathetic nerve activity in essential and secondary hypertension. Hypertension 31, 68-72. doi: 10.1161/01.HYP.31.1.68

Grassi, G., Seravalle, G., Bertinieri, G., Turri, C., Dell'Oro, R., Stella, M. L., et al. (2000). Sympathetic and reflex alterations in systo-diastolic and systolic hypertension of the elderly. J. Hypertens. 18, 587-593.16(12 Pt 2), 1979-1987. doi: 10.1097/00004872-200018050-00012

Gros, R., Chorazyczewski, J., Meek, M. D., Benovic, J. L., Ferguson, S. S., and Feldman, R. D. (2000). G-Protein-coupled receptor kinase activity in hypertension: increased vascular and lymphocyte G-protein receptor kinase-2 protein expression. Hypertension 35, 38-42. doi: 10.1161/01.HYP.35.1.38

Hambrecht, R., Gielen, S., Linke, A., Fiehn, E., Yu, J., Walther, C., et al. (2000). Effects of exercise training on left ventricular function and peripheral resistance in patients with chronic heart failure: a randomized trial. JAMA 283, 3095-3101. doi: 10.1001/jama.283.23.3095

Harding, V., Jones, L., Lefkowitz, R. J., Koch, W. J., and Rockman, H. A. (2001). Cardiac $\beta$ ARK1 inhibition prolongs survival and augments $\beta$ blocker therapy in a mouse model of severe heart failure. Proc. Natl. Acad. Sci. U.S.A. 98, 5809-5814. doi: 10.1073/pnas.091102398

Henriksen, E. J. (2002). Invited review: effects of acute exercise and exercise training on insulin resistance. J. Appl. Physiol. 93, 788-796. doi: 10.1152/japplphysiol.01219.2001

Huggett, R. J., Burns, J., Mackintosh, A. F., and Mary, D. A. (2004). Sympathetic neural activation in nondiabetic metabolic syndrome and its further augmentation by hypertension. Hypertension 44, 847-852. doi: 10.1161/01.HYP.0000147893.08533.d8

Hunt, S. A., Abraham, W. T., Chin, M. H., Feldman, A. M., Francis, G. S., Ganiats, T. G., et al. (2005). ACC/AHA (2005). Guideline Update for the Diagnosis and Management of Chronic Heart Failure in the Adult: a report of the American College of Cardiology/American Heart Association Task Force on Practice Guidelines (writing Committee to Update the 2001 Guidelines for the evaluation and Management of Heart Failure): developed in collaboration with the American College of Chest Physicians and the international society for Heart and Lung Transplantation: endorsed by the Heart rhythm society. Circulation 112, e154-e235. doi: 10.1161/CIRCULATIONAHA.105.167586
Iaccarino, G., Barbato, E., Cipolletta, E., De Amicis, V., Margulies, K. B., Leosco, D., et al. (2005). Elevated myocardial and lymphocyte GRK2 expression and activity in human heart failure. Eur. Heart J. 26, 1752-1758. doi: 10.1093/eurheartj/ehi429

Iaccarino, G., Tomhave, E. D., Lefkowitz, R. J., and Koch, W. J. (1998). Reciprocal in vivo regulation of myocardial $\mathrm{G}$ protein-coupled receptor kinase expression by $\beta$-adrenergic receptor stimulation and blockade. Circulation 98, 1783-1789. doi: 10.1161/01.CIR.98.17.1783

Judy, W. V., and Farrell, S. K. (1979). Arterial baroreceptor reflex control of sympathetic nerve activity in the spontaneously hypertensive rat. Hypertension 1, 605-614. doi: 10.1161/01.HYP.1.6.605

Julius, S., Gudbrandsson, T., Jamerson, K., Tariq Shahab, S., and Andersson, O. (1991). The hemodynamic link between insulin resistance and hypertension. J. Hypertens. 9, 983-986. doi: 10.1097/00004872-199111000-00001

Julius, S., and Nesbitt, S. (1996). Sympathetic overactivity in hypertension. A moving target. Am. J. Hypertens. 9, 113S-120S. doi: 10.1016/0895-7061(96)00287-7

Kaye, D. M., Lefkovitz, J., Jennings, G., Bergin, P., Broughton, A., and Esler, M. D. (1995). Adverse consequences of increased cardiac sympathetic activity in the failing human heart. J. Am. Coll. Cardiol. 26, 1257-1263. doi: 10.1016/07351097(95)00332-0

Kilts, J. D., Akazawa, T., Richardson, M. D., and Kwatra, M. M. (2002). Age increases cardiac $G$ alphai2 expression, resulting in enhanced coupling to G protein-coupled receptors. J. Biol. Chem. 277, 31257-31262. doi: 10.1074/jbc.M203640200

Koch, W. J., Rockman, H. A., Samama, P., Hamilton, R. A., Bond, R. A., Milano, C. A., et al. (1995). Cardiac function in mice overexpressing the $\beta$-adrenergic receptor kinase or a $\beta$ ARK inhibitor. Science 268, 1350-1353. doi: 10.1126/science.7761854

Kohno, K., Matsuoka, H., Takenaka, K., Miyake, Y., Okuda, S., Nomura, G., et al. (2000). Depressor effect by exercise training is associated with amelioration of hyperinsulinemia and sympathetic overactivity. Intern. Med. 39, 1013-1019. doi: 10.2169/internalmedicine.39.1013

Korner, P., Bobik, A., Oddie, C., and Friberg, P. (1993). Sympathoadrenal system is critical for structural changes in genetic hypertension. Hypertension 22, 243-252. doi: 10.1161/01.HYP.22.2.243

Krum, H., Schlaich, M., Whitbourn, R., Sobotka, P. A., Sadowski, J., Bartus, K., et al. (2009). Catheter-based renal sympathetic denervation for resistant hypertension: a multicentre safety and proof-of-principle cohort study. Lancet 373, 1275-1281. doi: 10.1016/S0140-6736(09)60566-3

Krum, H., Sobotka, P., Mahfoud, F., Bohm, M., Esler, M., and Schlaich, M. (2011). Device-based antihypertensive therapy: therapeutic modulation of the autonomic nervous system. Circulation 123, 209-215. doi: 10.1161/CIRCULATIONAHA.110.971580

Lambert, E., Straznicky, N., Schlaich, M., Esler, M., Dawood, T., Hotchkin, E., et al. (2007). Differing pattern of sympathoexcitation in normalweight and obesity related hypertension. Hypertension 50, 862-868. doi: 10.1161/HYPERTENSIONAHA.107.094649

Laterza, M. C., de Matos, L. D., Trombetta, I. C., Braga, A. M., Roveda, F., Alves, M. J., et al. (2007). Exercise training restores baroreflex sensitivity in never-treated hypertensive patients. Hypertension 49, 1298-1306. doi: 10.1161/HYPERTENSIONAHA.106.085548

Leosco, D., Iaccarino, G., Cipolletta, E., De Santis, D., Pisani, E., Trimarco, V., et al. (2003). Exercise restores beta-adrenergic vasorelaxation in aged rat carotid arteries. Am. J. Physiol. Heart Circ. Physiol. 285, H369-H374. doi: 10.1152/ ajpheart.00019.2003

Leosco, D., Rengo, G., Iaccarino, G., Filippelli, A., Lymperopoulos, A., Zincarelli, C., et al. (2007). Exercise and $\beta$-blocker treatment ameliorate age-impaired $\beta$-adrenergic receptor signaling and enhance cardiac responsiveness to adrenergic stimulation. Am. J. Physiol. Heart Circ. Physiol. 293, H1596-H1603. doi: 10.1152/ajpheart.00308.2007

Leosco, D., Rengo, G., Iaccarino, G., Golino, L., Marchese, M., Fortunato, F., et al. (2008). Exercise promotes angiogenesis and improves beta-adrenergic receptor signalling in the post ischaemic failing rat heart. Cardiovasc. Res. 78, 385-394. doi: $10.1093 / \mathrm{cvr} / \mathrm{cvm} 109$

Levy, N. W., Ng, M., Martin, P., and Zieske, H. (1966). Sympathetic and parasympathetic interactions upon the left ventricle of the dog. Circ. Res. 19, 5-10. doi: 10.1161/01.RES.19.1.5

Lundin, S., Ricksten, S. E., and Thoren, P. (1984). Renal sympathetic activity in spontaneously hypertensive rats and normotensive controls, as studied by 
three different methods. Acta Physiol. Scand. 120, 265-272. doi: 10.1111/j.17481716.1984.tb00133.x

Lymperopoulos, A., Rengo, G., Funakoshi, H., Eckhart, A. D., and Koch, W. J. (2007a). Adrenal GRK2 upregulation mediates sympathetic overdrive in heart failure. Nat. Med. 13, 315-323. doi: 10.1038/nm1553

Lymperopoulos, A., Rengo, G., and Koch, W. J. (2007b). Adrenal adrenoceptors in heart failure: fine-tuning cardiac stimulation. Trends Mol. Med. 13, 503-511. doi: 10.1016/j.molmed.2007.10.005

Lymperopoulos, A., Rengo, G., and Koch, W. J. (2012). GRK2 inhibition in heart failure: something old, something new. Curr. Pharm. Des. 18, 186-191. doi: 10.2174/138161212799040510

MacDonnell, S. M., Kubo, H., Crabbe, D. L., Renna, B. F., Reger, P. O., Mohara, J., et al. (2005). Improved myocardial beta-adrenergic responsiveness and signaling with exercise training in hypertension. Circulation 111, 3420-3428. doi: 10.1161/CIRCULATIONAHA.104.505784

Marciano, C., Galderisi, M., Gargiulo, P., Acampa, W., D’Amore, C., Esposito, R., et al. (2012). Effects of type 2 diabetes mellitus on coronary microvascular function and myocardial perfusion in patients without obstructive coronary artery disease. Eur. J. Nucl. Med. Mol. Imaging 39, 1199-1206. doi: 10.1007/s00259012-2117-9

Mueller, P. J. (2007). Exercise training attenuates increases in lumbar sympathetic nerve activity produced by stimulation of the rostral ventrolateral medulla. J. Appl. Physiol. 102, 803-813. doi: 10.1152/japplphysiol.00498.2006

Musch, T. I., Moore, R. L., Leathers, D. J., Bruno, A., and Zelis, R. (1986). Endurance training in rats with chronic heart failure induced by myocardial infarction. Circulation 74, 431-441. doi: 10.1161/01.CIR.74.2.431

Paolillo, S., Rengo, G., Pagano, G., Pellegrino, T., Savarese, G., Femminella, G. D., et al. (2013). Impact of diabetes on cardiac sympathetic innervation in patients with heart failure: a 123I meta-iodobenzylguanidine (123I MIBG) scintigraphic study. Diabetes Care 36, 2395-2401. doi: 10.2337/dc12-2147

Patel, K. P., Zhang, K., Zucker, I. H., and Krukoff, T. L. (1996). Decreased gene expression of neuronal nitric oxide synthase in hypothalamus and brainstem of rats in heart failure. Brain Res. 734, 109-115. doi: 10.1016/0006-8993(96) 00620-8

Petrofski, J. P., and Koch, W. J. (2003). The $\beta$-adrenergic receptor kinase ( $\beta$ ARK1) in heart failure. J. Mol. Cell. Cardiol. 35, 1167-1174. doi: 10.1016/S00222828(03)00243-8

Piepoli, M. F., Davos, C., Francis, D. P., Coats, A. J., and ExTraMATCH Collaborative. (2004). Exercise training metaanalysis of trials in patients with chronic heart failure (ExTraMATCH). BMJ 328, 189-195. doi: 10.1136/bmj.328.7441.711-b

Raake, P. W., Vinge, L. E., Gao, E., Boucher, M., Rengo, G., Chen, X., et al. (2008). $\mathrm{G}$ protein-coupled receptor kinase 2 ablation in cardiac myocytes before or after myocardial infarction prevents heart failure. Circ. Res. 103, 413-422. doi: 10.1161/CIRCRESAHA.107.168336

Rengo, G., Leosco, D., Zincarelli, C., Marchese, M., Corbi, G., Liccardo, D., et al. (2010). Adrenal GRK2 lowering is an underlying mechanism for the beneficial sympathetic effects of exercise training in heart failure. Am. J. Physiol. Heart Circ. Physiol. 298, H2032-H2038. doi: 10.1152/ajpheart.00702.2009

Rengo, G., Lymperopoulos, A., Leosco, D., and Koch, W. J. (2011). GRK2 as a novel gene therapy target in heart failure. J. Mol. Cell. Cardiol. 50, 785-792. doi: 10.1016/j.yjmcc.2010.08.014

Rengo, G., Lymperopoulos, A., Zincarelli, C., Donniacuo, M., Soltys, S., Rabinowitz, J. E., et al. (2009). Myocardial AAV6-BARKct gene therapy improves cardiac function and normalizes the neurohormonal axis in chronic heart failure. Circulation 119, 89-98. doi: 10.1161/CIRCULATIONAHA.108.803999

Rengo, G., Perrone-Filardi, P., Femminella, G. D., Liccardo, D., Zincarelli, C., de Lucia, C., et al. (2012a). Targeting the $\beta$-adrenergic receptor system through Gprotein-coupled receptor kinase 2: a new paradigm for therapy and prognostic evaluation in heart failure: from bench to bedside. Circ. Heart Fail. 5, 385-391. doi: 10.1161/CIRCHEARTFAILURE.112.966895

Rengo, G., Femminella, G. D., Liccardo, D., de Lucia, C., Pirozzi, E., Pagano, G., et al. (2012b). From bench to bedside: new insights into the treatment of heart failure. G. Ital. Cardiol. 13, 254-262. doi: 10.1714/1056.11557

Rengo, G., Zincarelli, C., Femminella, G. D., Liccardo, D., Pagano, G., de Lucia, C., et al. (2012c). Myocardial $\beta$ (2)-adrenoceptor gene delivery promotes coordinated cardiac adaptive remodelling and angiogenesis in heart failure. $\mathrm{Br}$. J. Pharmacol. 166, 2348-2361. doi: 10.1111/j.1476-5381.2012.01954.x
Rengo, F., Parisi, V., Rengo, G., Femminella, G. D., Rengo, C., Zincarelli, C., et al. (2012d). Instruments for geriatric assessment: new multidimensional assessment approaches. J. Nephrol. 25(Suppl. 19), S73-S78. doi: 10.5301/jn.5000164

Rengo, G., Lymperopoulos, A., Zincarelli, C., Femminella, G., Liccardo, D., Pagano, G., et al. (2012e). Blockade of $\beta$-adrenoceptors restores the GRK2-mediated adrenal $\alpha(2)$-adrenoceptor-catecholamine production axis in heart failure. $B r$. J. Pharmacol. 166, 2430-2440. doi: 10.1111/j.1476-5381.2012.01972.x

Rengo, G., Pagano, G., Squizzato, A., Moja, L., Femminella, G. D., de Lucia, C., et al. (2013a). Oral anticoagulation therapy in heart failure patients in sinus rhythm: a systematic review and meta-analysis. PLoS ONE 8:e52952. doi: 10.1371/journal.pone. 0052952

Rengo, G., Cannavo, A., Liccardo, D., Zincarelli, C., de Lucia, C., Pagano, G., et al. (2013b). Vascular endothelial growth factor blockade prevents the beneficial effects of $\beta$-blocker therapy on cardiac function, angiogenesis and remodeling in heart failure. Circ. Heart Fail. doi: 10.1161/CIRCHEARTFAILURE.113.000 329. [Epub ahead of print].

Rengo, G., Galasso, G., Femminella, G. D., Parisi, V., Zincarelli, C., Pagano, G., et al. (2013c). Reduction of lymphocyte $G$ protein-coupled receptor kinase-2 (GRK2) after exercise training predicts survival in patients with heart failure. Eur. J. Prev. Cardiol. doi: 10.1177/2047487313491656. [Epub ahead of print].

Rinaldi, B., Corbi, G., Boccuti, S., Filippelli, W., Rengo, G., Leosco, D., et al. (2006). Exercise training affects age-induced changes in SOD and heat shock protein expression in rat heart. Exp. Gerontol. 41, 764-770. doi: 10.1016/j.exger.2006.05.008

Rockman, H. A., Chien, K. R., Choi, D.-J., Iaccarino, G., Hunter, J. J., Ross, J. Jr., et al. (1998). Expression of a $\beta$-adrenergic receptor kinase 1 inhibitor prevents the development of heart failure in gene targeted mice. Proc. Natl. Acad. Sci. U.S.A. 95, 7000-7005. doi: 10.1073/pnas.95.12.7000

Rockman, H. A., Koch, W. J., and Lefkowitz, R. J. (2002). Seven-transmembranespanning receptors and heart function. Nature 415, 206-212. doi: $10.1038 / 415206 a$

Salazar, N. C., Vallejos, X., Siryk, A., Rengo, G., Cannavo, A., Liccardo, D., et al. (2013). GRK2 blockade with betaARKct is essential for cardiac beta2-adrenergic receptor signaling towards increased contractility. Cell Commun. Signal. 11, 64. doi: 10.1186/1478-811X-11-64

Savarese, G., Trimarco, B., Dellegrottaglie, S., Prastaro, M., Gambardella, F., Rengo, G., et al. (2013). Natriuretic peptide-guided therapy in chronic heart failure: a meta-analysis of 2, 686 patients in 12 randomized trials. PLoS ONE 8:e58287. doi: 10.1371/journal.pone.0058287

Schlaich, M. P., Lambert, E., Kaye, D., Krozowski, Z., Campbell, D. J., Lambert, G., et al. (2004). Sympathetic augmentation in hypertension. Role of nerve firing, norepinephrine reuptake, and angiotensin neuromodulation. Hypertension 43, 169-175. doi: 10.1161/01.HYP.0000103160.35395.9E

Schutzer, W. E., Reed, J. F., Bliziotes, M., and Mader, S. L. (2001). Upregulation of G protein-linked receptor kinases with advancing age in rat aorta. Am. J. Physiol. Regul. Integr. Comp. Physiol. 280, R897-R903.

Seals, D. R., and Esler, M. D. (2000). Human ageing and sympathoadrenal system. J. Physiol. 528, 407-417. doi: 10.1111/j.1469-7793.2000.00407.x

Shah, A. S., White, D. C., Emani, S., Kypson, A. P., Lilly, R. E., Wilson, K., et al. (2001). In vivo ventricular gene delivery of a $\beta$-adrenergic receptor kinase inhibitor to the failing heart reverses cardiac dysfunction. Circulation 103, 1311-1316. doi: 10.1161/01.CIR.103.9.1311

Simms, A. E., Paton, J. F., Pickering, A. E., and Allen, A. M. (2009). Amplified respiratory-sympathetic coupling in the spontaneously hypertensive rat: does it contribute to hypertension. J. Physiol. 587(Pt 3), 597-610. doi: 10.1113/jphysiol.2008.165902

Smith, P. A., Graham, L. N., Mackintosh, A. F., Stoker, J. B., and Mary, D. A. (2002). Sympathetic neural mechanisms in white-coat hypertension. J. Am. Coll. Cardiol. 40, 126-132. doi: 10.1016/S0735-1097(02)01931-9

Smith, P. A., Graham, L. N., Mackintosh, A. F., Stoker, J. B., and Mary, D. A. (2004). Relationship between central sympathetic activity and stages of human hypertension. Am. J. Hypertens. 17, 217-222. doi: 10.1016/j.amjhyper.2003.10.010

Spina, R. J., Turner, M. J., and Ehsani, A. A. (1998). Beta-adrenergic-mediated improvement in left ventricular function by exercise training in older men. Am. J. Physiol. 274, H397-H404.

Stratton, J. R., Cerqueira, M. D., Schwartz, R. S., Levy, W. C., Veith, R. C., Kahn, S. E., et al. (1992). Differences in cardiovascular responses to isoproterenol in relation to age and exercise training in healthy men. Circulation 86, 504-512. doi: 10.1161/01.CIR.86.2.504 
Stratton, J. R., Levy, W. C., Cerqueira, M. D., Schwartz, R. S., and Abrass, I. B. (1994). Cardiovascular responses to exercise. Effects of aging and exercise training in healthy men. Circulation 89, 1648. doi: 10.1161/01.CIR. 89.4.1648

Ungerer, M., Bohm, M., Elce, J. S., Erdmann, E., and Lohse, M. J. (1993). Altered expression of beta-adrenergic receptor kinase and beta 1- adrenergic receptors in the failing human heart. Circulation 87, 454-463. doi: 10.1161/01.CIR.87.2.454

van Tol, B. A., Huijsmans, R. J., Kroon, D. W., Schothorst, M., and Kwakkel, G. (2006). Effects of exercise training on cardiac performance, exercise capacity and quality of life in patients with heart failure: a meta-analysis. Eur. J. Heart Fail. 8, 841-850. doi: 10.1016/j.ejheart.2006.02.013

Wustmann, K., Kucera, J. P., Scheffers, I., Mohaupt, M., Kroon, A. A., de Leeuw, P. W., et al. (2009). Effects of chronic baroreceptor stimulation on the autonomic cardiovascular regulation in patients with drug-resistant arterial hypertension. Hypertension 54, 530-536. doi: 10.1161/HYPERTENSIONAHA.109. 134023

Xiao, R. P., Cheng, H., Zhou, Y. Y., Kuschel, M., and Lakatta, E. G. (1999). Recent advances in cardiac beta(2)-adrenergic signal transduction. Circ. Res. 85, 1092-1100. doi: 10.1161/01.RES.85.11.1092

Xiao, R. P., Spurgeon, H. A., O’Connor, F., and Lakatta, E. G. (1994). Age-associated changes in beta adrenergic modulation on rat cardiac excitation-contraction coupling. J. Clin. Invest. 94, 2051-2059. doi: 10.1172/JCI117559
Xiao, R. P., Tomhave, E. D., Wang, D. J., Ji, X., Boluyt, M. O., Cheng, H., et al. (1998). Age-associated reductions in cardiac betal- and beta2-adrenergic responses without changes in inhibitory $\mathrm{G}$ proteins or receptor kinases. J. Clin. Invest. 101, 1273-1282. doi: 10.1172/JCI1335

Conflict of Interest Statement: The authors declare that the research was conducted in the absence of any commercial or financial relationships that could be construed as a potential conflict of interest.

Received: 14 October 2013; paper pending published: 21 October 2013; accepted: 12 November 2013; published online: 28 November 2013.

Citation: Leosco D, Parisi V, Femminella GD, Formisano R, Petraglia L, Allocca E and Bonaduce D (2013) Effects of exercise training on cardiovascular adrenergic system. Front. Physiol. 4:348. doi: 10.3389/fphys.2013.00348

This article was submitted to Clinical and Translational Physiology, a section of the journal Frontiers in Physiology.

Copyright (c) 2013 Leosco, Parisi, Femminella, Formisano, Petraglia, Allocca and Bonaduce. This is an open-access article distributed under the terms of the Creative Commons Attribution License (CC BY). The use, distribution or reproduction in other forums is permitted, provided the original author(s) or licensor are credited and that the original publication in this journal is cited, in accordance with accepted academic practice. No use, distribution or reproduction is permitted which does not comply with these terms. 